Institute of $\mathbf{F}_{\text {ood and }} \mathbf{A g r i c u l t u r a l}_{\text {ciences }}$

\title{
Grandparents Raising Grandchildren: Building Relationships - Part $2^{1}$
}

Millie Ferrer and Angela Falcone ${ }^{2}$

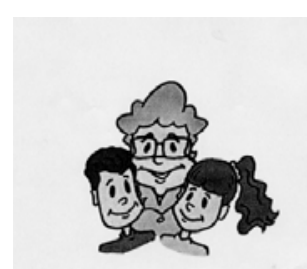

Goal: To provide grandparents with knowledge and skills to develop positive family relationships.

All families are unique and have different strengths. Building on strengths is necessary to maintain positive family relationships. In Grandparents Raising Grandchildren: Understanding Relationships - Part 1, we discussed the different feelings and lifestyle changes that can occur when a grandparent accepts the responsibility of raising a grandchild. We also discussed some characteristics of strong families. In this publication, you will learn how to enhance your coping skills and how to develop family building skills.

\section{Enhancing Your Coping Skills}

In your efforts to raise your grandchild, you need to take time to care for yourself. Raising your grandchild is a difficult task in and of itself. Without developing the appropriate coping skills, you may end up feeling more overwhelmed and frustrated than necessary. Taking care of yourself means taking time out to relax and reenergize. It also means seeking support from others.

\section{$\underline{\text { Self-care }}$}

You might be thinking that there is barely enough time to take care of your grandchild let alone re-energize yourself. However, it's essential to meet your personal needs in order to handle life's challenges. Do you remember a stressful time when you were tired and overwhelmed? Most likely, you were less patient and tolerant. Perhaps using coping

1. This document is FCS 2191-Eng, one of a series of the Department of Family, Youth and Community Sciences, Florida Cooperative Extension Service, Institute of Food and Agricultural Sciences, University of Florida. Publication date: January 2002. Reviewed by Anne Fugate, Project Coordinator, University of Florida, for Florida's CYFAR State Strengthening Grant, Maisie Ross, Extension Agent III, and Stephanie Toelle, Extension Agent III. Thanks to Erica Murphy, UF undergraduate student, for her support and assistance. Please visit the EDIS Web site at http://edis.ifas.ufl.edu

2. Millie Ferrer, Ph.D., Associate Professor, Human Development, and Angela Falcone, Ed.S., Graduate Assistant, Department of Family, Youth and Community Sciences, Cooperative Extension Service, Institute of Food and Agricultural Sciences, University of Florida, Gainesville, 32611.

The Institute of Food and Agricultural Sciences is an equal opportunity/affirmative action employer authorized to provide research, educational information and other services only to individuals and institutions that function without regard to race, color, sex, age, handicap, or national origin. For information on obtaining other extension publications, contact your county Cooperative Extension Service office. Florida Cooperative Extension Service / Institute of Food and Agricultural Sciences / University of Florida / Christine Taylor Waddill, Dean 
skill strategies would have eased some of your stress. Here are several coping skill strategies you can use whenever you are stressed:

- find a peaceful place to relax

- take a walk

- take up a hobby

- meditate

- let go of the

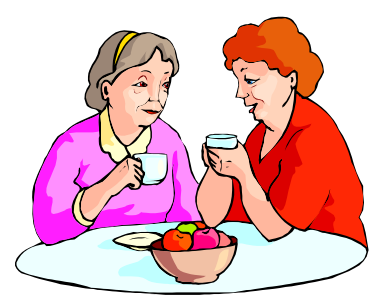
problem and come back to it later

- exercise, rest, and eat healthy

- practice stress reduction exercises

- learn to laugh at yourself

- watch a funny movie

- keep a positive thought journal

- revisit positive memories

The way we choose to think affects our coping skills. Its important to realize that many of the skills mentioned above will be more effective if you have a positive outlook.

Everything in life depends on the thoughts we choose to hold in our minds. Having faith in yourself will strengthen your ability to tackle your challenges. The following are some examples of seeing the glass as half-full instead of half-empty.

\begin{tabular}{||l|l||}
\hline \multicolumn{1}{|c|}{ Half-empty } & \multicolumn{1}{c||}{ Half-full } \\
\hline $\begin{array}{l}\text { This task is too } \\
\text { difficult for me. }\end{array}$ & $\begin{array}{l}\text { I'll do a little each day } \\
\text { until I get it done. }\end{array}$ \\
\hline $\begin{array}{l}\text { My grandchild talks } \\
\text { too much and asks } \\
\text { too many questions. }\end{array}$ & $\begin{array}{l}\text { My grandchild is } \\
\text { curious and eager to } \\
\text { learn. }\end{array}$ \\
\hline $\begin{array}{l}\text { It's impossible to find } \\
\text { time for myself. }\end{array}$ & $\begin{array}{l}\text { I'll find at least 15 } \\
\text { minutes to relax } \\
\text { today. }\end{array}$ \\
\hline
\end{tabular}

\section{Support From Others}

Sometimes it's impossible to face your challenges alone. All of us need and can benefit greatly from having friends, neighbors, and family to lend support. A circle of family and friends can:

- give encouragement

- act as a sounding board to discuss ideas and challenges

- cushion you against the stresses and strains of parenting your grandchild

- assist you in scheduling time for yourself

- provide additional adults who can make your grandchild feel special

Now that you know what you can gain from a support network, you're probably curious about how to establish one. For starters, you can meet people by joining a support group or starting one. For more information about starting a support group, contact AARP (see References at the end of this publication). You can also become more involved in community, school, or religious activities.

Opening yourself up to others will increase your chances of getting help. So, don't be afraid to ask others for what you need.

\section{Developing Family Building Skills}

Developing family building skills can make your family stronger. In this section, you will learn ways to build skills related to:
ÆE Beliefs and Values
C Healthy Boundaries
@ Ability to Adapt
( Good Communication 


\section{ÆE Beliefs and Values}

Sharing similar values unites and strengthens the family. Although values may differ among families, research shows that time together, commitment, and a positive outlook are consistent among strong families.

\section{Time together}

When you make time together a priority, you show that you appreciate your family. Family time can be as simple as reading to your grandchild or being with him* while he plays outside. Creating family traditions such as Sunday morning breakfasts, evening walks, or celebrating holidays are also ways of spending time together. Other activities you can enjoy together are sharing hobbies, participating in outdoor activities, and playing board games. Taking part in these activities creates everlasting memories and strengthen bonds.

How do you spend

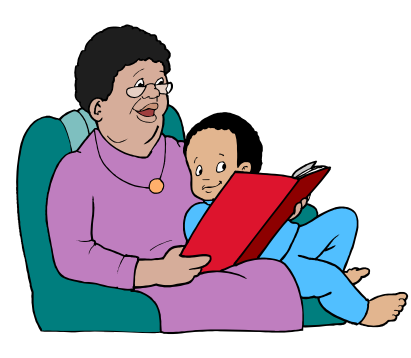
time together now?

What new activities are you willing to try?

\section{Commitment}

Families who value commitment are able to support each other through good and bad times. Keeping promises and sticking together through rough times are two ways to show commitment. Being loyal and not giving up on family members are other ways of showing commitment. Can you recall a time when your family demonstrated commitment?
Commitment takes time and effort to build. You can't expect it to blossom overnight. However, by sticking with a difficult family situation even when it seems hopeless, you can begin to develop this family value.

\section{Positive outlook}

As you recall, having a positive outlook is a necessary coping skill. Adopting a positive outlook is also an important ingredient for building strong family relationships. During tough times it is hard to be optimistic. As the family leader you can help your family find something positive in every situation.

One way of building a positive outlook is through rule setting. For example, you can establish a family rule of not allowing criticisms or put downs. Another way of building a positive outlook is through role modeling. You can dedicate yourself to setting a good example for your family by remaining hopeful and focusing on the positive strengths of each family member. By setting a good example, your family is more likely to develop a positive outlook.

\section{Healthy Boundaries}

In Understanding Relationships - Part 1, you learned that boundaries are limits you set in your relationships. Healthy boundaries need to be established when sharing feelings, setting expectations, and giving choices. But how do you know if you are setting a healthy boundary? One way to do this is to ask yourself several questions about the effects of your decisions. This will help you determine which option is most appropriate. 


\section{Sharing feelings}

How do you know if what you want to share with your grandchild is appropriate? You must consider how it will affect your grandchild. If you were to tell your grandchild the details of your experience, would he become more burdened, confused or overwhelmed? If so, it's probably not a good idea to share these details. Remember, sharing feelings is important. However, be selective and careful about sharing adult details. You don't want to create an unhealthy boundary.

\section{Setting expectations}

How do you know if the expectations you have for your grandchild are appropriate? You need to understand the physical, cognitive, social, and emotional stages of child development. For example, why would it be inappropriate to let your granddaughter, age 7, decide when to go to bed? At 7 years old, your granddaughter does not have the ability to understand the consequences of going to bed late. Why would it be appropriate to negotiate a bed time with your 14-year-old granddaughter? At this age, your granddaughter can understand the consequences of going to bed late.

\section{Giving choices}

How do you know when to give choices to your grandchild? Again, it is always important to consider your grandchild's ability to understand the effects of his actions. In addition, you need to consider the role you play in giving choices.

Are you the type of grandparent who makes all decisions for your grandchild? Or, are you the type of grandparent who is not involved when your grandchild makes decisions?

Being too controlling of a child's life breeds dependence and creates unhealthy boundaries. Children who are allowed to make decisions about their life feel better about themselves. On the other hand, being too permissive also creates an unhealthy boundary. When children have no adult to guide them in making decisions, they may overlook crucial consequences of their actions.

So, how do you find a balance between being too controlling and too permissive? Begin by asking yourself the following questions:

If I realize my behavior is too controlling...

- Can I trust my grandchild to do what he is ready to do?

- Am I willing to let him make safe decisions and learn from his mistakes?

- Can I let go for the sake of creating a healthy boundary?

If I realize my behavior is too permissive...

- Am I aware of the importance in guiding my grandchild's choices?

- Am I willing to provide support in helping him make decisions?

- Am I willing to play an active role in his life for the sake of creating a strong relationship?

\section{@Ability to Adapt}

Learning to adapt to change takes practice. It is not easy when you have a set way

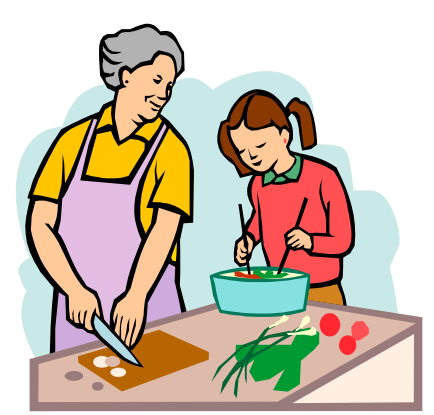


of believing or doing things. Adapting means making compromises and perhaps changing the way you accept certain situations. Described below are three situations. After reading the first two, identify the alternative which shows good adaptability. For number three, consider how you would respond to the situation. (See page 7 for answers and suggestions.)

1. You always have dinner ready at 5 p.m. Your grandchild has recently decided she wants to join the school band and will not get home till 6 p.m. You...

a) Change dinner time on band nights.

b) Tell her she can't join the school band.

2. You have always disliked long hair on men. Your grandson (age 15) decides to grow his hair long. You...

a) Tell him while living with you, he is not allowed to have long hair.

b) Permit him to have long hair. You realize this is a harmless way of expressing himself.

3. Before you had your grandchild, your house was always neat and clean. Now that you have your grandchild, the house is usually a mess. Your response to this situation is

Did your responses show adaptability? If so, then you're well on your way to building strong relationships. Remember, change is inevitable. By adjusting to new situations you can prevent unnecessary conflict.

\section{( Good Communication}

Good family communication opens the doors to healthy relationships. However, genuine communication is not always easy. It takes heartfelt commitment and effort by everyone in the family. There are certain barriers that can prevent good communication. Can you identify any communication barriers you've experienced? The following are some barriers to communication:

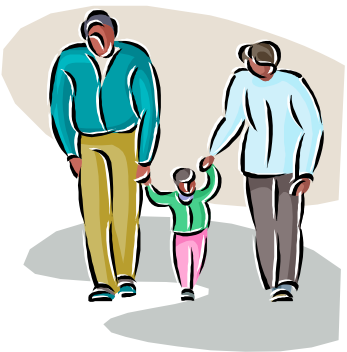

- jumping to conclusions

- using unkind words

- being self-centered

\section{Jumping to conclusions}

Jumping to conclusions can occur when we fail to listen to what another person is saying. We hear what we want to hear instead of what is actually said. Being a good listener means giving a person your undivided attention without interruptions. It means stopping and thinking before judging or reacting. To avoid this barrier, you need to make a commitment to listen, understand, and not be judgmental.

\section{Using unkind words}

Nothing destroys communication faster than the use of unkind words. When you use unkind words, people tend not to listen to you. They close up and are less likely to share their true feelings. Avoid words that ridicule, shame, and discourage family members. By focusing on the positive traits of each family member, you help create a 
climate of mutual love, respect, and good communication.

\section{Being self-centered}

Being self-centered means not being able to take the perspective of others. People who are self-centered are unable to put themselves in another person's shoes. They lack empathy. Having empathy is the ability to identify with and understand another person's feelings. When you communicate with your grandchildren, it's important to recognize and express your understanding of their feelings. It's easy to fall into the trap of listening only to words. But, when we only listen to a child's words we may miss the meaning of what is actually said. For example, a child's "I don't care," may mean "I'm frustrated, angry or sad." The key to understanding what the other person feels is to acknowledge his or her feelings. You might say, "You really seem upset," or "Your pain must be awful." When someone takes the time to understand our feelings, it can help us to feel loved and safe.

Acknowledging feelings is a skill. It takes practice. It is hard to respond to people especially if they are feeling unhappy, anxious, or angry. Many people rely on traditional responses, such as "Don't get so upset about it," or "I know just how you feel." Yet, when this happens we are really denying the person's feelings. Following are some exercises you can use to practice empathy statements. List the child's possible feeling and your response to this feeling. In your response, avoid asking questions or giving advice.
Example

Child: "Jennifer made fun of me in school."

Child's feeling: Embarrassment

Wrong response: What did you do to her?

Correct response: That must have been

embarrassing.

1. Grandparent: "Are you going to the movies with your friends?"

Child: " No, I don't like them anymore. I don't think I'm going."

Child's feeling:

Wrong response:

Correct response:

2. Child: "I hate my mom."

Child's feeling:

Wrong response:

Correct response:

3. Child: "I don't want Sarah (sister) using my clothes."

Child's feeling:

Wrong response:

Correct response:

Just as it is important for you to acknowledge your grandchild's feelings, it is also important for you to express your own feelings. By expressing your feelings you will be better understood. You can express your feelings by using "I" messages. When we don't use I messages, we can become self-centered and assume people understand what we are thinking and feeling. Using "I" messages may seem difficult, but with practice it will become easier.

"I" messages have four parts:

- situation - "When you..."

- feeling - "Ifeel..."

- reason - "Because..."

- expectation - "I would like you to..." 
Complete the "I" messages in the spaces below following the example given.

Scenario: Your grandson is two hours past curfew.

When you come home late, I feel worried and scared because I'm concerned about your safety. I would like you to call when you are going to be late.

1. Scenario: Your grandchild is always leaving his wet towels on the floor.

When you

Ifeel

because

I would like you to

2. Scenario: Your teenage granddaughters have been arguing and stopped speaking to one another.

When you

Ifeel

because

I would like you to

3. Scenario: Your grandchild's teacher has informed you that she has been misbehaving. When you

Ifeel

because

I would like you to

Developing the knowledge and skills required to have strong relationships takes practice and commitment. It's certainly not an easy task. But, be assured that the benefits outweigh all the hard work that is needed. The ways you guide and interact with your family will make an everlasting impact on your grandchild.

\section{Answers to Questions:}

\section{Ability to Adapt (page 5)}

1. a

2. $\mathrm{b}$

3. Good reaction: Set up rules and chores for cleaning. However, realize the house will never be as clean as before.

Good Communication: Being self-centered (Suggested answers; page 6 - 7)

You feelings (page 6):

1. Child's feeling: Rejected, sad, angry, hurt Wrong response: Why don't you want to go to the movies?

Correct response: You seem upset about it.

2. Child's feeling: Angry, resentful, abandoned, disappointed

Wrong response: Don't say you hate your mom.

Correct response: Sounds like you're really angry at Mom.

3. Child's feeling: Annoyed, frustrated, angry

Wrong response: You're being so selfish. Correct response: It annoys you when she borrows your clothes.

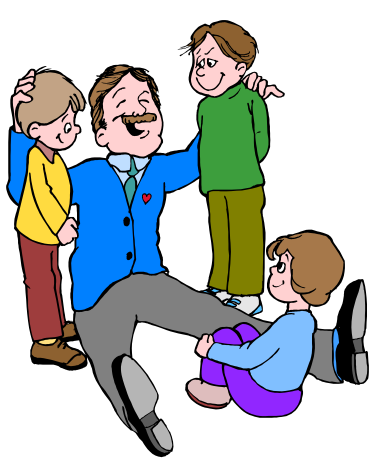


"I" messages (page 7):

1. When you leave your wet towels on the floor, I feel frustrated because I don't like picking up after you. I would like you to hang the towel up after using it.

2. When you give each other the silent treatment, I feel sad because the people I love are not getting along. I would like for you to sit down and try to work this out.

3. When you misbehave in school, I feel disappointed because I know you can follow rules and be both respectful and responsible. I would like for you to respect the classroom rules.

*This publication uses "he", "his", or "him" to represent children of both genders

\section{References:}

AARP (2001) Support Groups for Grandparents Raising Grandchildren.

http://www.aarp.org/confacts/health/grandsuppor $\underline{\text { t.html }}$

AARP Grandparent Information Center 601 E Street, NW

Washington, DC 20049

(202) 434-2296

Ferrer, M. (1999). Success and the single parent: Positive parenting - the communication puzzle. University of Florida, Cooperative Extension. 8pp. FCS 2145.

Ferrer, M. (1999) Success and the single parent: Taking care of yourself. University of Florida, Cooperative Extension. 8pp. FCS 2144.
Gottman, J. (1997). Raising an emotionally intelligent child. New York: Simon \& Schuster Inc.

Olson, D.H., \& DeFrain, J. (1997). Marriage and the family: diversity and strengths. Mountain View, CA. Mayfield Publishing Co.

Walsh, F. (1998). Strengthening family resilience. New York: Guilford Publication Inc. 